\title{
VACCINE INJURY - BURDEN OF PROOF OF THE DEFECT AND THE CAUSAL LINK IN THE LIGHT OF THE JUDGMENT IN THE CASE C-621/15
}

\author{
Katarina Knol Radoja, PhD, Assistant Professor \\ Josip Juraj Strossmayer University of Osijek, Faculty of Law \\ Stjepana Radića 13, Osijek, Croatia \\ kknol@pravos.hr
}

\begin{abstract}
In the European Union the liability of producers for harm caused by defective products manufactured or imported by them is regulated in Directive 85/374/EEC of 25 July 1985 on the liability for defective products. The purpose of Directive is to lay down a system of producer liability for damage caused by a defect in its product. Crucial is that it sets out a system of strict liability, so that the injured person does not have to show evidence of fault on the part of the producer. The injured person will have to prove the defect, the damage and the causal link between these. However, when it comes to the damage caused by vaccines, in case law the causal link has often been almost impossible to prove because in the scientific literature there are a number of opposing views on the risk of vaccination. Nevertheless, to the facilitation of the victims burden of proof could contribute the judgement of the Court of the European Union according to which a national court may consider that vaccination has led to the disease or damage even when there is no proof based on medical research. But, if there are other serious, specific and consistent evidence, such as the temporal proximity between the vaccination and the occurrence of a disease, the lack of personal and familiar history of that disease, together with the existence of other reported cases of the disease that occurred after such vaccines being received. Still, the Court retains caution by opposing any presumptions and warns that such cases are extremely fact-specific and require careful case-by-case considerations. In this article the author discusses the aforementioned judgement about liability for vaccine injury and its implications in the European Union.
\end{abstract}

Keywords: liability for defective products, vaccine, burden of proof, access to justice

\section{INTRODUCTION}

In scientific and professional literature is often stressed that the vaccination is the greatest public health achievement in history, that is preventing thousands of illnesses and deaths, ${ }^{1}$ and that, at the population level, risks of vaccines are small and

1 Miller, E. R.; Moro, P. L.,; Cano, M.; Shimabukuru, T. T., Deaths following vaccination: What does the evidence show?, Vaccine, vol. 33, issue 29., 2015, pp. 3288-3292 
balanced with the benefits of population immunization (so-called herd immunity). The theory of herd immunity is based on the immunization of a large number of individuals within the population thus reducing the possibility of spreading infection and contributing to the preservation of the public interest. ${ }^{2}$ In the exercise of this fundamental purposes of the immunization - the preservation of public health, there are potential benefits, but also burdens of human rights. ${ }^{3}$ Vaccines, though considered and designed for (preventive) protection against diseases, ${ }^{4} \mathrm{can}$ cause side effects ranging from mild to very severe. The most common side effects of vaccination are temperature, swelling, pain and redness at the injection site. Although serious side effects are less frequent, they include life-threatening allergic reactions, multiple sclerosis, brain inflammation, epileptic seizures, rheumatoid arthritis, and even death. ${ }^{5}$ Because of that, doubts about the safety ${ }^{6}$ of the vaccines are as old as vaccines themselves - dating back to the anticompulsory vaccination

$2 \quad$ Fine, P.; Eames, K.; Heymann, D. L., Herd Immunity: A Rough Guide, Clin. Infect. Dis., vol. 52, no. 7., 2011, pp. $911-916$

3 Habaus, L. K.; Holland, M. Vaccine Epidemic: How Corporate Greed, Biased Science, and Coercive Government Threaten Our Human Rights, Our Health, and Our Children, Skyhorse Publishing, Inc., New York, 2011

4 The assumption is that vaccination has affected a significant reduction in the number of diseased and deaths from contagious diseases. V. State of the world's vaccines and immunization, 3rd ed. Geneva: World Health Organization; 2009. Available at: [https://apps.who.int/iris/ bitstream/handle/10665/44169/9789241563864_eng.pdf;jsessionid=E0E650E2AAE62EFE954B2035AAD59006?sequence=1] Aaccessed 13.03.2019

5 The official data on reported side effects of vaccination in the Republic of Croatia can be found on the website of the Croatian Institute of Public Health. Available at: [https://www.hzjz.hr/sluzba-epidemiologija-zarazne-bolesti/nuspojave-cijepljenja-u-hrvatskoj/] Accessed 03.12.2018.; For more information about vaccine safety surveillance program run by CDC and the Food and Drug Administration (FDA) see the Vaccine Adverse Event Reporting System (VAERS), available at: [https://www.cdc.gov/ vaccinesafety/ensuringsafety/monitoring/vaers/index.html] Accessed: 03.01.2019

6 Some papers about the safety of some specific adjuvants in the vaccine, for ex.: Hooker B. S.; Kern, J.; Geier, D.; Haley, B.; Sykes, L.; King, P.; Geier, M., Methodological issues and evidence of malfeasance in research purporting to show thimerosal in vaccines is safe, Biomed. Research Int., vol. 2014, available at: [https://www.hindawi.com/journals/bmri/2014/247218/] Accessed 15.03.2019; Nakayama, T.; Aizawa, C.; Kuno-Sakai, H., A clinical analysis of gelatin allergy and determination of its causal relationship to the previous administration of gelatin-containing acellular pertussis vaccine combined with diphtheria and tetanus toxoids, The journal of allergy and clinical immunology, vol. 103, no. 2., 1999, pp. 321 - 325; Shaw, C. A., Tomljenovic L., Aluminum in the central nervous system (CNS): toxicity in humans and animals, vaccine adjuvants, and autoimmunity, Immunologic Research, vol. 56, issue 2-3., 2013., pp. 304-316. Some papers on questionable safety of a certain type of vaccine, for ex.: Hernan, M. et al., Recombinant Hepatitis B Vaccine and the Risk of Multiple Sclerosis a Prospective Study, Neurology, vol. 63, no. 5., 2004, pp. 838-842; Le Houézec, D., Evolution of multiple sclerosis in France since the beginning of hepatitis B vaccination, Immunologic Research, vol. 60, issue 2-3, 2014, pp. 219-225; Tomljenovic, L., Human papillomavirus (HPV) vaccine policy and evidence-based medicine: are they at odds?, Annals of medicine, vol. 45, no. 2., 2013, pp. 182-193 
league against mandated vaccination in the mid-1800s. ${ }^{7}$ Specifically, those who question the safety of vaccines emphasize that an individual sometimes carries a great burden for the benefit of the rest of the population. In its analysis of the human rights and responses to the challenges of public health, some authors even believe that health policies and programs could be considered discriminatory and burdensome for human rights until otherwise proven. ${ }^{8}$

A person who has been injured by the vaccine has the right for compensation. Since proving the liability for defective medical products is subject of analysed judgment of the Court of Justice of the European Union" (hereinafter: Court), this type of strict liability will primarily be a matter of the subject of this paper. In all member states of the European Union, strict liability for defective products was introduced in 1985 with Directive 85/374/EEC of 25 July 1985 on the approximation of the laws, regulations and administrative provisions of the Member States concerning liability for defective products (hereinafter: Directive on liability for defective products). ${ }^{10}$ While the liability based on fault is primarly focused on the behavior of the producer, strict liability is focused on characteristics of the product. In strict liability for damage an mitigating circumstance for the burden of proof is that there is no obligation to prove guilt of the defendant. On the other hand, in practice, particularly in proceedings for compensation for damage caused by the vaccine side effects, it is extremely difficult to prove another significant assumption of responsibility, a causal relationship and, in the case of liability for defective products, defect.

The aim of this paper is to recognize and analyze what is needed to be proven in the case of strict liability for a damage caused by the defective medical product ${ }^{11}$

Larson, H. J.; Cooper, L. Z.; Eskola, J.; Katz, S. L.; Ratzan, S., New Decade of Vaccines 5, Addressing the vaccine confi dence gap, Lancet, vol. 378, 2011, pp. 526-535; Spier, R. E., Perception of risk of vaccine adverse events: a historical perspective. Vaccine, vol. 20, 2001; pp. 78-84

8 Gostin, L.; Brennan, T.; Lazzarini, Z.; Fineberg, H., Health and Human Rights, in: Mann, J. M.; Gruskin, S., et.al (eds.), Health and Human Rights, Routledge, Taylor and Francis Group, New York, London, 1999., pp. 7-20; Acosta, Juana I., Vaccines, Informed Consent, Effective Remedy and Integral Reparation: an International Human Rights Perspective, Vniversitas, vol. 131, 2015, pp. 19 - 64

9 The Court of Justice of the European Union (Court) is institution of the European Union based in Luxembourg, and includes Court of Justice and General Court

10 Directive 85/374/EEC of 25 July 1985 on the approximation of the laws, regulations and administrative provisions of the Member States concerning liability for defective products (OJ L 210, 7.8.1985, p. $29-33$.

11 The term product from the Directive on liability for defective products includes all movables, with the exception of primary agricultural products and game, even though incorporated into another movable or into an immovable (art. 2. of the Directive on liability for defective products). Because of that, it also includes medical products. For more see: Hervey, T. K.; McHale, J. V., Health Law and the European Union, Cambridge University Press, 2004, p. 308 
- vaccine. When we talk about liability for damage caused by side effect of some medicinal product, first question is whether the medicinal product that caused the side effect shoud be classified as a defective product. Explicitly affirmative answer to this question would certainly have bad and demotivating effect on the development of medicine and the treatment of a range of diseases. Namely, it is clear that there is almost no such a medicinal product that does not have any side effects, they are easier or harder, and sometimes even with the most serious consequence death. Therefore, the very fact that some medicinal product is dangerous and has side effects may not necessarily mean that it is a defective product. The Directive on liability for defective products stipulates that a product is defective if it does not provide the safety that a person has the right to expect. ${ }^{12}$ But this Directive gives little indication on how this defectiveness should be assessed, as the standard set by Article 6 is extremely vague. ${ }^{13}$ Because of this subjectivity, courts must undertake a risk-benefit analysis to evaluate what an person may expect and to what extent is producer's care relevant. ${ }^{14}$ Maybe the hardest assumptions to prove the liability for defective product is causation. Therefore, in the practice so far, the courts have generally hardly accepted the possibility that the vaccines have side effects. ${ }^{15}$ It is a fact that in most medical studies the evidence to accept or reject a causal link between the vaccine and health impairment is inadequate. ${ }^{16}$ First of all, this is the consequence of the lack of consistent and concrete medical scientific evidence about the risks of vaccination. This is what also the European Court in the judgment of 21 June $2017^{17}$ has recognized, leaving the possibility of proving a defect of product and causal relationship on the basis of evidence that does not arise solely from medical research, about which more infra.

12 Art. 6. of the Directive on liability for defective products

13 Rajneri, E.; Borghetti, J.; Fairgrieve, D.; Rott, P., Remedies for Damage Caused by Vaccines: A Comparative Study of Four European Legal Systems, European Review of Private Law, 1-2018, pp. 57 - 96, p. 87

14 Cavaliere, A., Product Liability in the European Union: Compensationand Deterrence Issues, European Journal of Law and Economics, vol. 18, pp. 299 - 318., p. 302

15 For example, such an understanding is apparent from the judgment of the French Appeal Court of Paris of 7 March 2014, which, after case was returned to it on the occasion of the cassation appeal, found that there was no scientific consensus that between the vaccine against hepatitis $B$ and the occurrence of multiple sclerosis there is a causal link and that all national and international health authorities have refused to link the likelihood of the occurrence of this disease with the vaccine (from the judgement of the Court of Justice of the European Union, case C621/15, W and Others v Sanofi Pasteur MSD SNC, 21 June 2017., par. 16.); Knol Radoja, K., Naknada štete prouzročene cijepljenjem, Zbornik Pravnog fakulteta u Rijeci, vol. 39, no. 1., 2018, pp. 507 - 534, p. 514

16 Stratton, K.; Ford, A.; Rusch, E.; Wright Clayton, E., Adverse Effects of Vaccines: Evidence and Causality, Committee to Review Adverse Effects of Vaccines, Institute of Medicine, (ed.), Washington, DC: The National Academies Press., 2012, available at: [http://vaccine-safety-training.org/tl_files/vs/ pdf/13164.pdf] Accesed 04.12.2018

17 Decision of the Court of Justice of the European Union in case C621/15, W and Others $v$ Sanofi Pasteur MSD SNC, 21 June 2017. (hereinafter: Decision) 
The author concludes that the existence of medical evidence should not be the only criterion for deciding on a causal relationship, since the Directive on liability for defective products does not give any special probative strenght to any of these types of evidence, so also the other relevant evidence must be taken into account. Relying on certain evidence alone unduly hampers the ability of the national court to assess all relevant evidence and thus violates the right to a fair trial. The right to a fair trial in the European Convention is guaranteed by Article 6. In considering the aspects of Article 6 of the Convention, we can cite the words of prof. Uzelac who number the following elements of the right to fair trial: access to court, legal aid and advice, equality of arms, public hearing, fair hearing, rights to proof, public pronouncement of judgments, tribunal established by law, impartiality and independence, reasonable time, effective enforcement, legal certainty and ban of arbitrariness. $^{18}$

\section{LIABILITY FOR DAMAGE}

Due to the perceived vaccine safety problems there is visible increasing trend of refusing or delaing of recommended vaccination. ${ }^{19} \mathrm{~A}$ series of literature has been written about the conflict between the public interest and the individual's right to reject vaccination, ${ }^{20}$ but there is no final consensus at EU level, so in some states within the EU vaccination is prescribed as optional and somewhere as compulso-

18 Uzelac, A., Pravo na pošteno suđenje: opći i građanski aspekti čl. 6. st. 1. Europske konvencije za zaštitu ljudskih prava $i$ temeljnih sloboda, in: Usklađenost zakonodavstva i prakse sa standardima Europske konvencije za zaštitu ljudskih prava i temeljnih sloboda (ed. Radačić, I.), Centar za mirovne studije, Zagreb, 2011., pp. 89-125

19 Siddiqui, M., Salmon, D. A., Omer, S.B., Epidemiology of vaccine hesitancy in the United States, Hum. Vaccin. Immunother., vol. 9, 2013, pp. 2643 - 2648

20 Tucak, I., Legal and Ethical Justification of Compensation Regarding Compulsory Vaccination Injuries, Facta Universitatis, Law and Politics, vol. 15, no. 2., 2017, pp. 145 - 155; Jefferson, T., Vaccination and its adverse effects: real or perceived. Society should think about means of linking exposure to potential long-term effect, British Medical Journal, vol. 317, 1998, pp. 159 - 160; Andorno, R., Global Bioethics at UNESCO: In Defence of the Universal Declaration on Bioethics and Human Rights, Journal of Medical Ethics, vol. 33, no. 3., pp. 150-154; Neustaedter, R., The Vaccine Guide: Risks and Benefits for Children and Adults, 2nd ed., North Atlantic Books, Berkeley, 2002; MorItz, A., Vaccine-Nation: Poisoning the Population, One Shot at a Time, Ener-Chi Wellness Center, Morris, Illinois, 2011; Allen, A., Vaccine: the Controversial Story of Medicine's Greatest Lifesaver, WW Norton \& Company, New York, 2007; Offit, P. A., Deadly Choices: How the Anti-Vaccine Movement Threatens Us All, Basic Books, New York, 2011 
ry. ${ }^{21}$ In states where vaccination is mandatory, giving informed consent ${ }^{22}$ to this preventive medical procedure remains only at the declarative level because legal possibilities of rejection are almost unfeasible. On the other hand, the states that give people the right to choose, but through comprehensive education and by providing complete information encourage them on voluntary vaccination, they often, by the number of general screening, achieve better results. This policy is not only ethically acceptable but can also contribute to savings on claims for damages. ${ }^{23}$ But regardless of whether vaccination is mandatory or optional, the existence of an elaborated system of compensation is essential. In a number of states, various programs of out-of-court compensation have been for this purpose established, ${ }^{24}$ while in some states, such as in the Republic of Croatia, the injured parties can rely solely on judicial protection. Court proceedings can be difficult and long-lasting, but in medical disputes, due to the injuries of close persons, along with these, emotionally and financially exhausting. In addition, also the labeling of a passively legitimate person in these cases is often confusing and it is unclear whether to sue a physician, institution (eg. health center), state, vaccine manufacturer or all of them. In these proceedings, it is often questionable whether the defendants are liable for compensation based on subjective or strict liability. ${ }^{25}$

For the formation of liability stipulated assumptions, such as the existence of subjects, damaging action, damage and causal link between harmful act and damage, must be fulfilled. In some cases are required also special assumptions, such as the existence of gulit, increased risk of harm, a special relationship between the offender and the responsible person etc. According to these specific assumptions are distinguished different types of liability, the rules on the possibility of limiting or exempting from liability, the ways of repairing the damage and the amount of

21 In the Republic of Croatia, mandatory vaccination is prescribed against several, mostly children's infectious diseases. In its decision of 30 January 2014 concerning the proposal to review the constitutionality of the Law on the protection of the population against infectious diseases (Official Gazette, no. 79/07., 113/08., 43/09.) the Constitutional Court of the Republic of Croatia states that the vaccination is aimed to eliminate infectious diseases from the total population, which is a positive obligation of the state and which the legislator wants to achieve by stipulating the general obligation of the vaccination against certain infectious diseases. Constitutional court also considers that such an approach of the legislator falls within the scope of its discretion and that it does not extend beyond the constitutional framework (Decision of the Constitutional Court of the Republic of Croatia no.: U-I-5418/2008 of 30 January 2014)

22 Acosta, op. cit. note 8, p. 25

23 Tucak, I., Obvezno cijepljenje djece: za i protiv, in: Rešetar, B.; Aras Kramar, S.; Lucić, N.; Medić, I.; Šago, D.; Tucak, I.; Mioč, P., Suvremeno obiteljsko pravo i postupak, Pravni fakultet u Osijeku, Osijek, 2017, pp. $137-165$, p. 16

24 For more see: Knol Radoja, op. cit. note 15

25 Ibid. 
compensation. According to whether for the liability to be established the guilt of the offender is needed, liability can be subjective or strict (causal). For example, pursuant to the Croatian Civil Obligations Act (hereinafter: COA), ${ }^{26}$ a person who has caused damage to another person, if he has not proven that the damage has not happen because of his fault, shall compensate for this damage. ${ }^{27}$ However, side effects associated with the vaccine rarely appear due to negligence and most often there is no simple way to prove someone's guilt. ${ }^{28}$ The health care professional and/ or the institution is responsible for the adverse consequences of the medical procedure when in the conduct of its employees, under principle of guilt, the existence of elements of liability are determined. This means that there would be liability if a failure was made during the vaccination procedure or the vaccination was carried out contrary to the generally accepted rules for that type of medical procedure, which would be in a causal relation with the health condition of the injured party which is claiming for damage compensation. ${ }^{29}$ According to the principle of guilt, liability also exists, if there has been a lack of due attention, if the physician does not check the health status of the child before vaccination or in accordance with the Croatian Act about medicinal products ${ }^{30}$ does not determine whether the vaccine passed necessary testing prior being placed on the market. ${ }^{31}$ The strict liability is imposed regardless of the fault and exists where damage results from things or activities that are considered to be dangerous for the environment. ${ }^{32}$

Special form of strict liablity is strict liability of the producer, which is the primarly subject of this paper. The rules of strict liability of the producer apply to damages that may arise as a result of the defect of a product. In the Republic of Croatia the liability of the producer is thoroughly regulated in the $\mathrm{COA}^{33}$ (in articles 1073-1080). As a Memmber State of EU, the Republic of Croatia has the obligation to act in accordance with EU law, so this provisions are in accordance with EU Directive on liability for defective products. According to this Directive (and COA) the producer bears the liability for the damage if the damage is caused because of a defect in his

\footnotetext{
26 Civil Obligations Act, Official Gazette, no. 35/05, 41/08, 125/11, 78/15

27 Art. 1045/1 COA

28 For more see: Looker, C.; Kelly, H., No-fault Compensation Following Adverse Events Attributed to Vaccination: A Review of International Programmes, Bulletin of the World Health Organization, 2011., pp. 371 -378; available at: [http://www.who.int/bulletin/volumes/89/5/10-081901/en/] Accesed 29.11.2018

29 Knol Radoja, op. cit. note 15, p. 514

30 Act about medicinal products, Official Gazette, no. 76/13, 90/14

31 Knol Radoja, op. cit. note 15, p. 514

32 Art. 1045/3 COA

33 Civil Obligations Act, op. cit. note 26
} 
product. ${ }^{34}$ Also, any person who imports a product for sale, hire, leasing or any form of distribution in the course of his business will be responsible as a producer. ${ }^{35}$ To prove the liability for the defective product, the injured person will have the burden to prove "the damage, the defect and the causal relationship between defect and damage. ${ }^{36}$ By the evaluation of the medical product, ${ }^{37}$ all circumstances, such as its presentation, the use to which it could be put and the time when it was put into distribution, must be taken into account. Apart from the obvious defects such as expiration of use, defective packaging, etc., analysis of Article 6 of the Directive on liability for defective products leads to the conclusion that it is of crucial importance the expected level of safety. According to the Directive 2004/27/EC of the European Parliament and of the Council of 31 March 2004 amending Directive 2001/83/EC on the Community code relating to medicinal products for human use ${ }^{38}$ the package leaflet must be clear and understandable, enabling the users to act properly, when needed with the support of health professionals. The package leaflet of the medicinal product must be clearly readable in the official language of the Member State in which is put on the market. Therefore, a medicinal product will be defective if the level of the danger of the product is not clearly indicated to the intended recipients and because of that undermines certainty about the risks. And this makes it necessary to analyse whether is the level of danger of the product clearly indicated and is there sufficient information on contraindications and side effects of medicinal product. ${ }^{39}$ If it is found that the vaccine was not defective, liability will generally exist if it is proven the fault of the defendant according to the general rules on liability. ${ }^{40}$ From proving that the product is defective it is even more difficult to prove the causation. The burden of proof of a causation is also on the plaintiff. ${ }^{41}$ Hard provability of a causal relationship between vaccination and damage often is result of the fact that the damage sometimes occurs after a few weeks or even months. ${ }^{42}$ Prooving damage

\footnotetext{
34 Art. 1. of the Directive on liability for defective products

35 Arg. ex. Art. 3. of the Directive on liability for defective products

36 Art. 4. of the Directive on liability for defective products.

37 Baretić, M., Product Liability in Medicine, in Beran R. (eds), Legal and Forensic Medicine, Berlin, 2003, p. 1805; Art. 4. of the Directive on liability for defective products

38 Directive 2004/27/EC of the European Parliament and of the Council of 31 March 2004 amending Directive 2001/83/EC on the Community code relating to medicinal products for human use, Official Journal L 136, 30/04/2004 P. 0034 - 0057

39 Article 63. of the Directive 2004/27/EC of the European Parliament and of the Council of 31 March 2004 amending Directive 2001/83/EC on the Community code relating to medicinal products for human use

40 Baretić, op. cit. note 37, p. 1805

${ }^{41}$ Arg. ex. Art. 4. Directive on liability for defective products

42 Keelan, J.; Wilson, K., Balancing Vaccine Science and National Policy Objectives: Lessons From the National Vaccine Injury Compensation Program Omnibus Autism Proceedings, Am. J. Public Health. vol. 101, no. 11., 2011, pp. $2016-2021$
} 
due to the side effects of vaccination will be extremely difficult, in practice sometimes impossible, because in the scientific literature there are many controversial standpoints on the risks of vaccination and the medical professionals generally claim that there is no specific medical scientific evidence that confirms that vaccines cause damage. However, the existence of one certain evidence such as medical evidence, should not be only criterion for deciding on a causal relationship. That is also what has, in analized decision, ${ }^{43}$ the Court of Justice of the European Union concluded, leaving the possibility of proving a causal relationship based on evidence that does not arise from medical research.

\section{THE COURT OF JUSTICE OF THE EUROPEAN UNION (JUDGMENT OF 21 JUNE 2017 IN CASE C-621/15 WAND OTHERS V SANOFI PASTEUR MSD SNC).}

The Court of Justice of the European Union has recently, in Case C-621/15 W and Others $v$ Sanofi Pasteur MSD SNC, made a pronouncement on the interpretation of the provision of the Directive on liability for defective products in the light of damage caused by vaccine. Namely, on the basis of the Treaty on the Functioning of the European Union, ${ }^{44}$ (hereinafter: TFEU) national courts have been able to raise questions about the interpretation and application of Union law before the Court. Court is competent to decide on the previous issues concerning the interpretation of the Treaty and of acts of the other institutions, offices, bodies or agencies of the EU. ${ }^{45}$ Therefore, if such a question ${ }^{46}$ arises before any court of a Member State, that court may request the Court to give a ruling about it. The legal doctrine found that this procedure before the Court played a central role in the development of the legal system of the Union and has through uniform interpretations contributed to the harmonization of EU law. ${ }^{47}$ The decisions made in the preliminary procedure have erga omnes effect and thus are binding not only for the state from which the issue is addressed but also for all other Member States. ${ }^{48}$

\footnotetext{
$43 \quad$ Decision op. cit. note 17

44 Treaty on the Functioning of the European Union 2012/C 326/01, OJ C 326, 26.10.2012, p. 47 - 390

45 Article 267 TFEU

46 Into consideration come only questions concerning European Union law and which are raised before the court of a Member State. Procedures about general or hypothetical issues are not subject of Article 267. TFEU. Broberg, M., Fenger, N., Preliminary references to the European Court of Justice, Oxford University Press, Oxford, 2010, pp. 105 -117; Case C-244/80 Foglia v. Novello (no. 2) [1981] ECR 3045, par. 18

47 De la Mare, T., Donnelly, C., Preliminary Rulings and EU Legal Integration: Evolution and Stasis, in: Craig, P.; De Búrca, G., The Evolution of EU Law, Oxford University Press, New York, 2011, pp. 363 - 404

48 Craig, P.; de Búrca, G., EU Law, Oxford University Press, New York, 2003., p 442; Goldner Lang, I., Učinci presuda Europskog suda u prethodnom postupku, in: Ćapeta, T.; Goldner Lang, I; Perišin, T.; Ro-
} 
Therefore, every individual in proceedings before the national court may invoke on the law of the Union but also on the Court's jurisprudence and the national courts are obliged to apply it. The failure of a Member State's court to apply the EU legal norm in the way that Court interprets it can lead to serious violations of Union law and, in some cases, the State's liability. Member States are therefore liable if other persons are harmed by the fact that the state did not in time or failed to comply with the Directive or has applied a different norm of European Union law. ${ }^{49}$ The general conditions of liability for damage Court has been set up in joined cases Francovich i Bonifaci, ${ }^{50}$ and in joined cases Brasserie du Pêcheur i Factortame. ${ }^{51}$ The special form of liability of the judges that have failed to fulfill the obligation to refer the preliminary question is defined in the case Köbler. ${ }^{52}$

In view of the above mentioned effect, the Court's decision on the preliminary question on the liability for defective products could be of importance in proving defect of product and causal relationship between vaccination and damage. With its erga omnes effect at the level of the national courts of the EU Member States it confirms the parties' right to a fair trial in which all evidences have equal strength. The judgment was delivered on the request for the preliminary ruling concerning the interpretation of Article 4 of the Directive on liability for defective products, sent by the french Cour de Cassation, and received by the Court on 23 November 2015.

\subsection{The circumstances of the case}

The circumstances of the case are the following: Mr. W. received three hepatitis B vaccines (manufactured by Sanofi Pasteur) between December 1998. and July 1999. His health problems began in August 1999, culminated in November 2000. with the diagnosis of multiple sclerosis and and finally in 2011 with death. In year $2006 \mathrm{Mr}$. W. and his family initiated proceedings for compensation of damage before the French court against Sanofi Pasteur. They claimed a producer to be

din, S. (eds.), Prethodni postupak u pravu Europske unije, suradnja nacionalnih sudova s europskim sudom, Narodne novine, Zagreb, 2011, pp. 89 - 93

49 For more see: Ćapeta, T., Odgovornost država za štetu u pravu Europske zajednice, Zbornik Pravnog fakulteta u Zagrebu, vol. 53, 200., pp. 3 - 4

50 Joined cases Francovich and Bonifaci (C-6/90 i C-9/90 Andrea Francovich and Danila Bonifaci and others v. Italian Republic (1991) ECR I-5357)

51 Joined cases Brasserie du Pêcheur and Factortame (C-46/93 i C-48/93 Brasserie du Pêcheur SA v. Bundesrepublik Deutschland and The Queen v. Secretary of State for Transport, ex parte: Factortame Ltd and others (1996) ECR I-1029)

52 Case C-224/01 Gerhard Köbler v. Republik Österreich (2003) ECR I-10239. In the Köbler case Court stated that the court is obliged to initiate the preliminary proceedings under Art. 267 TFEU, and if it did not do so and misapplies the EU law, there are grounds for claiming compensation for damage from the State 
liable for damage because of a product defect. They argued that the close timing between the vaccination and the beginning of symptoms of his illness, as well as the lack of any family or personal history of the disease gave rise to specific, serious and consistent presumptions about the existence of a defect in the vaccine, and a causal link between it and the development of the multiple sclerosis. ${ }^{53}$

The litigation has going through a various instances of French courts that have taken different standpoints. So the Regional Court of Nanterre at first instance upheld the claim, but by the Court of Appeal of Versailles it was subsequently overturned. The latter court held that the relied evidence was sufficient to establish presumptions capable of proving a causation between the vaccination and the manifestation of the disease but were not sufficient to establish a vaccine's defect. However, Court of Cassation quashed this decision. ${ }^{54}$ The case was sent before the Court of Appeal of Paris which again overturned the first instance judgment. For purposes of this paper, the most important thing that the Court of Appeal of Paris pointed out is that there is no scientific consensus that support a causation between the vaccination and multiple sclerosis and that all the health authorities, international and national, had rejected the correlation between this disease and the vaccination. In the light of various elements, the Court of Appeal of Paris concluded that the criteria relating to time interval between receiving of the vaccines and the occurrence of first symptoms and the lack of personal and family backgrounds could not, together or individually, establish specific, serious and consistent presumptions that support the conclusion of there being a causation between the vaccination and the multiple sclerosis. ${ }^{55}$ In those events, after new appeal brought by W and Others against that judgment, in 2015 the Court of Cassation decided to address to the Court for a preliminary ruling.

\subsection{Proving the defect and the existence of a causal relationship}

The first important issue the Court had decided was can the Article 4 of Directive, in the area of liability of pharmaceutical laboratories for the vaccines that they manufacture, be interpreted as precluding. The problem was in a method of proof by which the court is ruling on the merits. Namely, whether "the court may consider that the facts relied on by the applicant constitute serious, specific and consistent presumptions capable of proving the defect in the vaccine and the existence of a causal relationship between it and the disease, notwithstanding the finding that medical research does not establish a relationship between the vaccine and

Decision, op. cit. note 17 , par. 11

Ibid, par. $12-15$

Ibid, par. 16 
the occurrence of the disease. ${ }^{" 56}$ In its reasoning the Court poited out that if the only method of proof a plaintiff can rely on is medical research, it would be excessively difficult or even impossible to establish liability of the producer, and would undermine the effectiveness of Directive. ${ }^{57}$ Because of that, the Court answered that Article 4 of Directive must be interpreted in the way that a national court may consider that, despite the finding that medical research neither establishes nor rules out the existence of a causal link between vaccination and the disease, certain factual evidence "constitutes serious, specific and consistent evidence enabling it to conclude that there is a defect in the vaccine and that there is a causal link between that defect and that disease." ${ }^{58}$

Second and third question was about establishing presumptiones. In the doctrine appeared concerns about this questions because the Court ruled that national courts may use the same evidence to conclude that there is a defect in the vaccine as they do to conclude that there is a causal link between that defect and the disease. ${ }^{59}$ It is stated that this seems to open the door to lower courts' decisions that would consider vaccine, in this case vaccine for hepatitis B, as defective because this product has been presumed to cause severe disease in one given case, even though its global risk/benefit ratio remains positive. ${ }^{60}$ But we must not forget that the Court stated that Article 4 of Directive "must be interpreted as precluding evidentiary rules based on presumptions according to which, where medical research neither establishes nor rules out the existence of a link" between the vaccination and the disease, the existence of causation between the defect of the vaccine and the damage will always be supposed to be established when some predetermined evidence is given. ${ }^{61}$ Court argued that such a irrefutable presumption would result that the producer would be deprived of opportunity to carry out facts and even scientific arguments to disprove that presumption, and the court would not be able to evaluate all the facts. Being so automatic would destabilize the principle of burden of proof lay out in Article 4 of Directive, and risk the effectiveness of the system of liability established by that Directive. ${ }^{62}$ Also, even if the presumption were to be refutable, the producer could, even before the courts ruling, find itself in the situation of having to invalidate that presumption in order to successfully

\footnotetext{
Ibid, par. 17

Ibid, par. 31

Ibid, par. 43

Rajneri; Borghetti; Fairgrieve; Rott, op. cit. note 13, p. 88

Ibid.

Decision, op. cit. note 17 , par. 55

Ibid, par. 53
} 
defend itself. This would also result that the burden of proof provided for in $\mathrm{Ar}$ ticle 4 of Directive would be neglected. ${ }^{63}$

\subsection{Commentary on the Decision}

An example from the French judiciary suggests that there is a danger that sometimes in court proceedings is, at the expense of other evidence, too much attention paid to certain types of evidence. Court's decision confirms the right of the national court to assess all relevant evidence without questioning whether it can make a decision without some specific evidence. That such a decision obviously was necessary arises also from some criticisms of the judgement that soon came. The critics state that such a decision makes a distortion of science and insensibility to the legitimate methods that generate scientific knowledge in the context of vaccines. ${ }^{64}$ Critics consider that, in relation to other evidences in this case, to the relevant scientific evidence should be given greater respect because of the method by which it was produced. ${ }^{65}$ However, despite the fact that scientific knowledge arises from specific methods which are based on testing the hypothesis "against the data, though a process of systematic process of observation and experimentation", ${ }^{66}$ scientific methods also, as the critics themselves admit, "tend to be naturally progressive and forwardthinking." ${ }^{\prime} 7$ Therefore, because once some scientific discoveries were considered true, this does not mean that they will forever be perceived as such. They must be subject to equal treatment and re-examination as any other evidence. Also, how the Advocate General Bobek in his Opinion states, the Directive does not necessitate that certain weight should be given to scientific or medical research..$^{68}$ In addition, he states that Article 4 of the Directive regulates burden of proof but does not dictate kind of evidence, methods, standard of proof or the weight to be given to partucular evidence. ${ }^{69}$ The Directive also does not stipulate that absence of medical research establishing a causation is convincing proof of absence of defect or causal link. The Directive only obliges the establishment of a causation between defect

\footnotetext{
63 Ibid, par. 54

64 Smillie, L. R.; Eccleston-Turner, M. R., Cooper, S. L., C-621/15 - W and Others v Sanofi Pasteur: An Example of Judicial Distortion and Indifference to Science, Med. Law Review, vol. 26, no. 1., 2018, pp. $134-145$

65 Ibid.

66 Ibid.

67 Ibid.

68 Opinion of Advocate General Bobek delivered on 7 March 2017 in Case C621/15 W and Others v Sanofi Pasteur MSD SNC Caisse primaire d'assurance maladie des Hauts-de-Seine-Caisse Carpimko, par. 39

69 Ibid. par. 40
} 
and damage. ${ }^{70}$ As stated by the Advocate General Bobek, it has been acknowledged by the Court that, when determinating rules of proof and evidence, Member States may restore imbalances between the consumer and the producer, which sometimes result from information asymmetry. That option reflects the broader EU law requirements of access to justice. ${ }^{71}$ Advocate General underlines that, in line with the principle of procedural autonomy, it is on each Member State to determine comprehensive rules of proof for implementation of the Directive. ${ }^{72}$ However, the procedural autonomy of Member States in laying down that rules is not unlimited. The effect of national rules must obey to the principles of effectiveness and equivalence. ${ }^{73}$ Therefore, national rules of proof that inhibit the court's ability to assess relevant evidence, or that in practice result in a reversal of the burden of proof, would not be consistent with this principles. Which ultimately may bring to a breach of the principle of effective judicial control or the right to a fair trial. ${ }^{74}$ To this we can add the argument that any limitation of the freedom of evidence evaluation would be a violation of the principle of seeking for the truth and would return us to a system of formal search for truth. However, experience shows that this system does not ensure the attainment of absolute truth in the modern stage of development of the judicial investigation. Only a lack of legal constraints can create a platform for achieving satisfactory results. Therefore, during the free evaluation of evidence it is the duty of the court to conscientiously and carefully evaluate each evidence individually and all the evidence together and make its decision on the basis of the results of the entire procedure. ${ }^{75}$

Critics also argue that these judicial approaches may fuel the vaccine scepticism in Europe. ${ }^{76}$ They warn the Court to be mindful to not encourage the give a cover to ideas that "benefits of vaccines do not outweigh concerns about the harm they may cause" without the scientific evidence for doing so. ${ }^{77}$ However, the Court did not rule on the facts of case, only on questions of law. The Court's decision does not mean that vaccines can be blamed for every damage without scientific evidence, but it means that the scientific evidence does not have the exclusive power, and it is necessary to take all the circumstances of the case into account. Besides that, with this critic we could not agree because, although the Court has stated that a

\footnotetext{
$70 \quad$ Ibid, par. 42

$71 \quad$ Ibid. par. 23

$72 \quad$ Ibid. par. 21

$73 \quad$ Ibid. par. 24

$74 \quad$ Ibid. par. 25

75 For more see: Triva, S.; Dika, M., Gradansko parnično procesno pravo, Narodne novine, Zagreb, 2004, pp. $158-173$

76 Smillie, op. cit. note 64

77 Ibid.
} 
national judge may consider that some factual evidence "constitutes serious, specific and consistent evidence" allowing it to decide that there is a defect and a causal relationship, ${ }^{78}$ what Court specifically emphasized is that, despite the existence of such indications, Article 4 of Directive must be interpreted as precluding evidentiary rules based on presumptions. Court also highlights that the use of such presumptions would undermine Article 4 and would risk the very effectiveness of the system of liability that the Directive introduced..$^{79}$ In addition to that and although critics state that this judgement might have an impact on the increase number of liability claims for vaccine harm, Stein, an expert in civil (medical) liability law, for Nature magazine said that "credible medical evidence showing that the vaccine is safe will win the case" and "those who say that the Court decision has opened a floodgate for multiple vaccine liability suits are therefor mistaken." ${ }^{80}$ Also, he adds that, if courts would have to use only scientific methods of proof, "they would hardly be able to make decisions and to deliver timely justice to people." 81

\section{CONCLUSION}

In many cases, the causal link between damage and the vaccine is difficult, if not impossible, to prove. This is partly because damage from the side effect of the vaccine sometimes occurs after days, weeks or even months after vaccination, but also because the vaccine safety studies are often opposed and inadequat. ${ }^{82}$ Despite the increasing number of opponents of the vaccine and the allegations on its side effects, medical experts generally state that there is no concrete scientific medical evidence that confirms that the vaccine cause harm and generally promote a high level of vaccination rate in the population for the purpose of public health protection (so-called herd immunity). However, making only medical proof a prerequisite for establishing products' defects and causation with its discouraging effect indirectly denies plaintiffs right to a fair trial. As stated by the Advocate General Bobek, such a high evidentiary standard, which are excluding any method of proof other than medical proof, could make it hard or even impossible to de-

78 Decision, op. cit. note 17 , par. 43

$79 \quad$ Ibid, par. 55 and 57

80 Castells, L.; Butler, D., Vaccine ruling from Europe's highest court isn't as crazy as scientists think, Nature, June 28, 2017, available at: [https://www.nature.com/news/vaccine-ruling-from-europe-s-highestcourt-isn-t-as-crazy-as-scientists-think-1.22222] Accessed 27.01.2019

81 Ibid.

82 For some studies see: CDC, available at: [https://www.cdc.gov/vaccinesafety/research/publications/index.html] Accessed 29.01.2019; Vaccine Safety Commission, available at: [https://vaccinesafetycommission.org/studies.html] Accessed 29.01.2019 
termine liability of the producer. In such cases, the national court's freedom to evaluate evidence would be excessively inhibited. ${ }^{83}$

The recent ruling of the Court in case W and Others $v$ Sanofi Pasteur MSD SNC is "balanced and in line with long-standing legal traditions," ${ }^{4}$ but it surely contributes to clarifying the basic principles of product liability across the EU. Because of the issue of interpretation of the analyzed provisions of the Directive on liability for defective products the case has been stretched for several years at different instances of French courts. This decision strikes a more judicious balance because it affirms an individual's right to sue producer of defective product for harms that were not reasonably expected. ${ }^{85}$ Namely, it confirms to the national courts the ability to assess all relevant evidence without considering and questioning whether it may make a decision without some specific evidence. With its interpretation, the Court may influence that the same does not happen again before some another national court of the EU Member State, possibly Croatian. In accordance with this judgment, if certain factual evidence constitutes serious, specific and consistent evidence, such as the temporal proximity between the vaccination and the manifestation of a disease, the lack of history of that disease and the existence of other similar reported cases, this may lead a national court to consider that a injured person has fulfilled his burden of proof. In this case, taking all circumstances into account, the national court can consider that the vaccine does not offer the safety that the patient may expect. ${ }^{86}$

However, the Court also points out that national courts may not use evidentiary rules based on presumptions. Namely, if the existence of a causation would be automatically presumed, the producer could find itself, even before the courts had the opportunity to hear producer's arguments, in the position that he must strike that presumption in order to defend himself. Such a situation would lead to the burden of proof being ignored ${ }^{87}$ In view of the above, it is important to emphasize that the interpretation of the decision of the Court should not result in the reversal of the burden of proof to the defendant. The burden to prove damage, defect and causation has to remain with the plaintiff. A reversal is not allowed. ${ }^{88}$

\footnotetext{
83 Opinion, op. cit. note 68, par. 45

84 Castells; Butler, op. cit. note 80

85 Holland, Mary S., Liability for Vaccine Injury: The United States, the European Union, and the Developing World, Emory Law Journal, vol. 67, 2018, pp. 415 - 462., p. 459

86 Decision, op. cit. note 17 , par. 41

$87 \quad$ Ibid., par. 54

88 Verheyen, T., Full Harmonization, Consumer Protection and Products Liability: A Fresh Reading of the Case Law of the ECJ, European Review of Private Law vol. 1-2018, pp. 119 - 140, p. 124
} 


\section{REFERENCES}

\section{BOOKS AND ARTICLES}

1. Acosta, Juana I., Vaccines, Informed Consent, Effective Remedy and Integral Reparation: an International Human Rights Perspective, Vniversitas, vol. 131, 2015, pp. $19-64$

2. Allen, A., Vaccine: the Controversial Story of Medicine's Greatest Lifesaver, WW Norton \& Company, New York, 2007

3. Andorno, R., Global Bioethics at UNESCO: In Defence of the Universal Declaration on Bioethics and Human Rights, Journal of Medical Ethics, vol. 33, no. 3, pp. $150-154$

4. Baretić, M., Product Liability in Medicine, in: Beran R. (eds), Legal and Forensic Medicine, Berlin, 2003

5. Broberg, M.; Fenger, N., Preliminary references to the European Court of Justice, Oxford University Press, Oxford, 2010, pp. $105-117$

6. Cavaliere, A., Product Liability in the European Union: Compensationand Deterrence Issues, European Journal of Law and Economics, vol. 18, pp. 299 - 318

7. Craig, P.; de Búrca, G., EU Law, Oxford University Press, New York, 2003

8. Cooper, L. Z.; Larson, H. J.; Katz, S. L., Protecting public trust in immunization, Pediatrics, 2008, pp. 149-153

9. Ćapeta, T., Odgovornost država za štetu u pravu Europske zajednice, Zbornik Pravnog fakulteta u Zagrebu, vol. 53, no. 3-4, 2003

10. De la Mare, T.; Donnelly, C., Preliminary Rulings and EU Legal Integration: Evolution and Stasis, in: Craig, P.; De Búrca, G., The Evolution of EU Law, Oxford University Press, New York, 2011, pp. $363-404$

11. Descamps, D.; Hardt, K.; Spiessens, B.; Izurieta, P.; Verstraeten, T.; Breuer, T.; Dubin G., Safety of human papillomavirus (HPV)-16/18 AS04-adjuvanted vaccine for cervical cancer prevention: a pooled analysis of 11 clinical trials, Human Vaccines, vol. 5, no. 5, 2009, pp. 332-340

12. Fine, P.; Eames, K.; Heymann, D. L., Herd Immunity: A Rough Guide, Clin. Infect. Dis., vol. 52, no. 7, 2011, pp. $911-916$

13. Goldner Lang, I., Učinci presuda Europskog suda u prethodnom postupku, in: Ćapeta, T.; Goldner Lang, I.; Perišin, T.; Rodin, S. (eds.), Prethodni postupak u pravu Europske unije, suradnja nacionalnih sudova s europskim sudom, Narodne novine, Zagreb, 2011, pp. 89 $-93$

14. Gostin, L.; Brennan, T.; Lazzarini, Z.; Fineberg, H., Health and Human Rights, in: Mann, J. M.;Gruskin, S., et.al. (eds.), Health and Human Rights, Routledge, Taylor and Francis Group, New York, London, 1999

15. Habaus, L. K.; Holland, M. Vaccine Epidemic: How Corporate Greed, Biased Science, and Coercive Government Threaten Our Human Rights, Our Health, and Our Children, Skyhorse Publishing, Inc., New York, 2011

16. Hernan M. et al., Recombinant Hepatitis B Vaccine and the Risk of Multiple Sclerosis a Prospective Study, Neurology, vol. 63, no. 5, 2004, pp. 838-842 
17. Hervey, T. K.; McHale, J. V., Health Law and the European Union, Cambridge University Press, 2004

18. Hviid, A.; Hansen, J. V.; Frisch, M.; Melbye, M., Measles, Mumps, Rubella Vaccination and Autism: A Nationwide Cohort Study, Ann. Intern. Med., 2019., available at: [https://annals.org/aim/fullarticle/2727726/measles-mumps-rubella-vaccination-autism-nationwidecohort-study] Accessed 15.03.2019

19. Holland, Mary S., Liability for Vaccine Injury: The United States, the European Union, and the Developing World, Emory Law Journal, vol. 67, 2018, pp. 415 - 462

20. Hooker B. S.; Kern, J.; Geier, D.; Haley, B.; Sykes, L.; King, P.; Geier, M., Methodological issues and evidence of malfeasance in research purporting to show thimerosal in vaccines is safe, Biomed. Research Int., vol. 2014, available at: [https://www.hindawi.com/journals/ bmri/2014/247218/] Accessed 15.03.2019

21. Jefferson, T., Vaccination and its adverse effects: real or perceived. Society should think about means of linking exposure to potential long-term effect, British Medical Journal, vol. 317, 1998, pp. $159-160$

22. Jefferson, T.; Heijbel, H., Demyelinating disease and hepatitis B vaccination: is there a link?, Drug Safety, vol. 24, no. 4, 2001, pp. $249-254$

23. Keelan, J.; Wilson, K., Balancing Vaccine Science and National Policy Objectives: Lessons From the National Vaccine Injury Compensation Program Omnibus Autism Proceedings, Am. J. Public Health. vol. 101, no. 11, 2011, pp. 2016 - 2021

24. Keith, L. S.; Jones, D. E.; Chou, C. H., Aluminum toxicokinetics regarding infant diet and vaccinations, Vaccine, vol. 20, suppl. 3, 2002, pp. 13-17

25. Knol Radoja, K., Naknada štete prouzročene cijepljenjem, Zbornik Pravnog fakulteta u Rijeci, vol. 39, no. 1, 2018, pp. $507-534$

26. Larson, H. J.; Cooper, L. Z.; Eskola, J.; Katz, S. L.; Ratzan, S., New Decade of Vaccines 5, Addressing the vaccine confi dence gap, Lancet, vol. 378, 2011, pp. 526-535

27. Le Houézec, D., Evolution of multiple sclerosis in France since the beginning of hepatitis $B$ vaccination, Immunologic Research, vol. 60, issue 2-3, 2014, pp. 219-225

28. Miller, E. R.; Moro, P. L.; Cano, M.; Shimabukuru, T. T., Deaths following vaccination: What does the evidence show?, Vaccine, vol. 33, issue 29, 2015, pp. 3288-3292

29. Moritz, A., Vaccine-Nation: Poisoning the Population, One Shot at a Time, Ener-Chi Wellness Center, Morris, Illinois, 2011

30. Nakayama, T.; Aizawa, C.; Kuno-Sakai, H., A clinical analysis of gelatin allergy and determination of its causal relationship to the previous administration of gelatin-containing acellular pertussis vaccine combined with diphtheria and tetanus toxoids, The journal of allergy and clinical immunology, vol. 103, no. 2, 1999, pp. 321 - 325

31. Neustaedter, R., The Vaccine Guide: Risks and Benefits for Children and Adults, 2nd ed., North Atlantic Books, Berkeley, 2002

32. Offit, P. A., Deadly Choices: How the Anti-Vaccine Movement Threatens Us All, Basic Books, New York, 2011 
33. Rajneri, E.; Borghetti, J.; Fairgrieve, D.; Rott, P., Remedies for Damage Caused by Vaccines: A Comparative Study of Four European Legal Systems, European Review of Private Law, 1-2018, pp. $57-96$

34. Shaw, C. A.; Tomljenovic L., Aluminum in the central nervous system (CNS): toxicity in humans and animals, vaccine adjuvants, and autoimmunity, Immunologic Research, vol. 56, issue 2-3, 2013, pp. 304-316

35. Siddiqui, M.; Salmon, D. A.; Omer, S. B., Epidemiology of vaccine hesitancy in the United States, Hum. Vaccin. Immunother., vol. 9, 2013, pp. $2643-2648$

36. Smillie, L. R.; Eccleston-Turner, M. R.; Cooper, S. L., C-621/15 - W and Others v Sanofi Pasteur: An Example of Judicial Distortion and Indifference to Science, Med. Law Review, vol. 26, no. 1, 2018, pp. $134-145$

37. Spier, R. E., Perception of risk of vaccine adverse events: a historical perspective. Vaccine, vol. 20, 2001, pp. 78-84

38. Tomljenovic, L., Human papillomavirus (HPV) vaccine policy and evidence-based medicine: are they at odds?, Annals of medicine, vol. 45, no. 2, 2013, pp. 182-193

39. Triva, S.; Dika, M., Gradansko parnično procesno pravo, Narodne novine, Zagreb, 2004

40. Tucak, I., Legal and Ethical Justification of Compensation Regarding Compulsory Vaccination Injuries, Facta Universitatis, Law and Politics, vol. 15, no. 2, 2017, pp. 145 - 155

41. Tucak, I., Obvezno cijepljenje djece: za i protiv, in: Rešetar, B.; Aras Kramar, S.; Lucić, N.; Medić, I.; Šago, D.; Tucak, I.; Mioč, P. (eds.), Suvremeno obiteljsko pravo i postupak, Pravni fakultet u Osijeku, Osijek, 2017, pp. 137 - 165

42. Uzelac, A., Pravo na pošteno sudenje: opći i gradanski aspekti čl. 6. st. 1. Europske konvencije za zaštitu ljudskih prava i temeljnih sloboda, in: Radačić, I. (ed.), Usklađenost zakonodavstva i prakse sa standardima Europske konvencije za zaštitu ljudskih prava i temeljnih sloboda, Centar za mirovne studije, Zagreb, 2011, pp. 89 - 125

43. Verheyen, T., Full Harmonization, Consumer Protection and Products Liability: A Fresh Reading of the Case Law of the ECJ, European Review of Private Law, vol. 1-2018, pp. 119 - 140

\section{COURT OF JUSTICE OF THE EUROPEAN UNION}

1. Case C621/15, W and Others $v$ Sanofi Pasteur MSD SNC, 21 June 2017

2. Case C-244/80 Foglia v. Novello (no. 2) [1981] ECR 3045, par. 18

3. Joined cases Francovich and Bonifaci (C-6/90 i C-9/90 Andrea Francovich and Danila Bonifaci and others v. Italian Republic (1991) ECR I-5357)

4. Joined cases Brasserie du Pêcheur and Factortame (C-46/93 i C-48/93 Brasserie du Pêcheur SA v. Bundesrepublik Deutschland and The Queen v. Secretary of State for Transport, ex parte: Factortame Ltd and others (1996) ECR I-1029)

5. C-224/01 Gerhard Köbler v. Republik Österreich (2003) ECR I-10239.

6. Opinion of Advocate General Bobek delivered on 7 March 2017 in Case C621/15 WXY $v$ Sanofi Pasteur MSD SNC Caisse primaire d'assurance maladie des Hauts-de-Seine-Caisse Carpimko 


\section{EU LAW}

1. Directive $85 / 374 /$ EEC of 25 July 1985 on the approximation of the laws, regulations and administrative provisions of the Member States concerning liability for defective products, Official Journal L 210, 7.8.1985, p. 29 - 33

2. Directive 2004/27/EC of the European Parliament and of the Council of 31 March 2004 amending Directive 2001/83/EC on the Community code relating to medicinal products for human use, Official Journal L 136 , 30/04/2004 P. 0034 - 0057

3. Treaty on the Functioning of the European Union 2012/C 326/01, Official Journal C 326, 26.10.2012, p. $47-390$

\section{LIST OF NATIONAL REGULATIONS, ACTS AND COURT DECISIONS}

1. Civil Obligations Act, Official Gazette, no. 35/05, 41/08, 125/11, 78/15

2. Act about medicinal products, Official Gazette, no. 76/13, 90/14

3. Decision of the Constitutional Court of the Republic of Croatia no.: U-I-5418/2008 of 30 January 2014

\section{WEBSITE REFERENCES}

1. State of the world's vaccines and immunization, 3rd ed. Geneva: World Health Organization; 2009.; available at: [https://apps.who.int/iris/bitstream/handle/10665/44169/9789241563864_ eng.pdf;jsessionid=E0E650E2AAE62EFE954B2035AAD59006? sequence=1] Accessed 13.03.2019

2. Croatian Institute of Public Health. Available at: [https://www.hzjz.hr/sluzba-epidemiologija-zarazne-bolesti/nuspojave-cijepljenja-u-hrvatskoj/] Aaccessed 03.12.2018

3. Vaccine Adverse Event Reporting System (VAERS), available at: [https://www.cdc.gov/vaccinesafety/ensuringsafety/monitoring/vaers/index.html] Accessed 03.12.2018

4. Stratton, K.; Ford, A.; Rusch, E.; Wright Clayton, E., Adverse Effects of Vaccines: Evidence and Causality, Committee to Review Adverse Effects of Vaccines, Institute of Medicine, (ed.), Washington, DC: The National Academies Press., 2012, available at: [http://vaccinesafety-training.org/tl_files/vs/pdf/13164.pdf] Accesed 04.12.2018

5. Looker, C.; Kelly, H., No-fault Compensation Following Adverse Events Attributed to Vaccination: A Review of International Programmes, Bulletin of the World Health Organization, 2011., pp. 371.-378; available at: [http://www.who.int/bulletin/volumes/89/5/10-081901/ en/] Accesed 29.11.2018

6. Castells, L.; Butler, D., Vaccine ruling from Europe's highest court isn't as crazy as scientists think, Nature, June 28, 2017, available at:[https:/www.nature.com/news/vaccine-ruling-from-europe-s-highest-court-isn-t-as-crazy-as-scientists-think-1.22222] Accessed 29.11.2018

7. CDC, available at: [https://www.cdc.gov/vaccinesafety/research/publications/index.html], Accessed 29.01.2019

8. Vaccine Safety Commission, available at: [https://vaccinesafetycommission.org/studies. html] Accessed 29.01.2019 